REGULAR ARTICLE

\title{
PROXIMATE, PHYTOCHEMICAL, AND SENSORY EVALUATION OF "UZA- AKWUAGWORAGWO" TRADITIONAL FOOD OF NKANU PEOPLE IN ENUGU STATE, NIGERIA
}

\author{
AGOMUO EMMANUEL ${ }^{*}$, EBOAGWU IJEOMA², NWADIKECONSTANCE3, EZEKWE \\ AHAMEFULA4, ONEDIBE OZIOMA5
}

\author{
${ }^{1}$ Department of Biochemistry, Imo State University, Owerri, Nigeria \\ ${ }^{2}$ Department of Food Technology, Federal Institute of Industrial Research Oshodi, Nigeria \\ 3Department of Medical Laboratory Science, Imo State University, Owerri, Nigeria \\ 4Department of Medical Biochemistry, Imo State University, Owerri, Nigeria \\ 5Department of Chemical Science (Biochemistry Unit), Rhema University, Aba, Nigeria
}

\begin{abstract}
Proximate, phytochemical, and sensory evaluation of "uza-akwuagworagwo" traditional food were investigated using standard

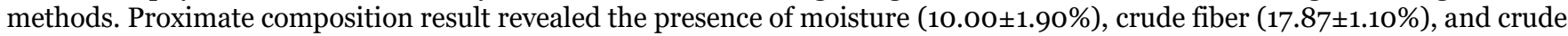

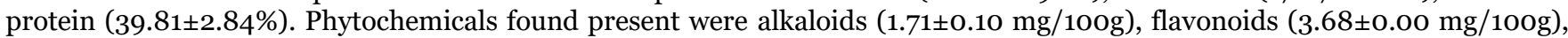
and tannins (0.64 $\pm 0.12 \mathrm{mg} / 100 \mathrm{~g})$. Sensory evaluation attributes of the food such as appearance (5.31 \pm 0.29$)$, taste (7.00 \pm 1.02$)$, color $(6.22 \pm 0.92)$ and overall acceptability $(6.10 \pm 0.31)$ were also observed in the study. The high protein content of the studied food could mean that it can contribute significantly to daily protein requirement of the body when consumed. The low levels of phytochemicals found in the food could be an added health advantage. The sensory evaluation of the food compares to those of other traditional foods. This study has revealed the proximate, phytochemical, and sensory evaluation of "uzaakwuagworagwo" traditional food of Nkanu people in Enugu State, Nigeria.
\end{abstract}

Keywords: Cuisines, Ethnic national, Proximate composition, Sensory evaluation, Traditional foods

\section{INTRODUCTION}

The desire to survive followed the existence of man on this planet Earth [1-2]. From time immemorial, the attribute of searching for different medicinal therapies [3-5] and foods has been associated with man [1]. Food has been defined comprehensively as any material which when ingested, digested and assimilated provides the body with energy, promotes growth and replaces worn out cells [6-11]. According to Amadi et al. [11], foods can be rooted on tradition and custom of the people. They can bear continental names such as African foods, European foods, Japanese foods, and etcetera; and also country names such as Nigerian foods, Ghanaian foods, and Ethiopian foods [2, 9, 12-13]. Such foods are mostly of plant origin, with phytochemicals and phytonurients [14-17].

Most African foods are recognizable cuisines that are specific to a particular set of people [18]. In Nigeria for instance, most foods are associated with a particular ethnic national, group, locality, community or society [17]. According to Amadi et al. [19], such foods are known as traditional foods $[12,20]$.
Traditional foods are valued because they showcase the cutlery tradition of the people and have a lot of benefits on health [13, 20-25]. However, many factors limited the transfer of knowledge on how they are prepared as well as their benefits on consumption [10, 26-29].

"Uza-akwuagworagwo" traditional food is among the traditional foods with limited knowledge on how they are prepared as well as their benefits on consumption due to change in lifestyle and taste. "Uza-akwuagworagwo" is a traditional food consumed by the people of Nkanu in Enugu State, Southeastern Nigeria. Nkanu people speak Igbo as their dialect. The people of Nkanu are mainly farmers while few are traders. This traditional food unifies and projects the tradition and custom of Nkanu people. With the renewed interest on traditional foods, there is need to extend the study on traditional foods to accommodate those ones that are still in existence, unravel their possible health benefits on consumption and acceptability.

The present study is geared towards this area, and

\footnotetext{
Received o7 November 2017; Accepted 30 December 2017

*Corresponding Author
}

Agomuo Emmanuel

Department of Biochemistry, Imo State University, Owerri, Nigeria

Email: dmkcoo7@gmail.com

(C) This article is open access and licensed under the terms of the Creative Commons Attribution License (http://creativecommons.org/licenses/by/4.o/) which permits unrestricted, use, distribution and reproduction in any medium, or format for any purpose, even commercially provided the work is properly cited. Attribution - You must give appropriate credit, provide a link to the license, and indicate if changes were made. 
investigated the proximate, phytochemical and sensory evaluation of "Uza-akwuagworagwo" traditional food.

\section{MATERIALS AND METHODS}

\section{Sample collection}

"Uza-akwu" (brown mung beans, botanitically known as Vigna radiate), palm oil, pepper, crayfish, onion, salt, smoked fish, and maggi spice were purchased from a local market within Nkanu.

\section{Procedure of "Uza-akwuagworagwo"}

Tiny stones and debris were first removed from the purchased one kilogram of "uza-akwu". The stone and debris free "uza-akwu" was further separated into good and damaged ones. The damaged ones got discarded while the good ones were soaked into a bowel of water for twelve hours to shorten cooking hours. The soaked "uza-akwu" was then placed in a pot and four litres of water was added and then boiled for three hours and thirty minutes before it was confirmed consumption fit. The remaining water used in cooking "uza-akwu" was filtered off into an empty clean container. One and half (1.5) grams of ground pepper, $100 \mathrm{~g}$ of smoke fish, $250 \mathrm{ml}$ of palm oil, $18 \mathrm{~g}$ of ground crayfish, $8 \mathrm{~g}$ of maggi spice, and $100 \mathrm{~g}$ of onions in sliced form were added and mixed together with the cooked "uza-akwu". While mixing the whole components, the filtered water earlier used in cooking the "uza-akwu" was gradually added at interval. Finally, $75 \mathrm{~g}$ of salt was added to taste and mixed to form "uza-akwuagworagwo" ready to be served.

\section{Preparation of sample for analysis}

The prepared "uza-akwuagworagwo" was oven dried at 70 ${ }^{\circ} \mathrm{C}$ for $48 \mathrm{~h}$, the dried food sample was grinded using hand mill device to ground sample, which was stored in an air tight container till needed for analysis.

\section{Proximate analysis}

Moisture, crude protein, crude fat, ash, fibre and available carbohydrate content of the studied sample was determined using the methods of AOAC [30]. Atwater factor method as described by Onyeike et al. [31] was used for evaluation of the energy values of the studied sample.

\section{Determination of percentage free fatty acid}

Ten gram of sample was weighed into a $100 \mathrm{ml}$ roundbottomed flask and refluxed with $6 \mathrm{ml}$ of methanolic solution of $\mathrm{NaOH}(0.5 \mathrm{~mol} / \mathrm{l})$. Ten $\mathrm{ml}$ of heptane was then added and heated for one more minute. The heater was switched off and saturated solution of $\mathrm{NaCl}$ was added and shaken in a circular fashion. The flask was allowed to cool for phase separation. One $\mathrm{ml}$ of the upper layer of the separated phase was pipette into gas chromatograph for analysis.

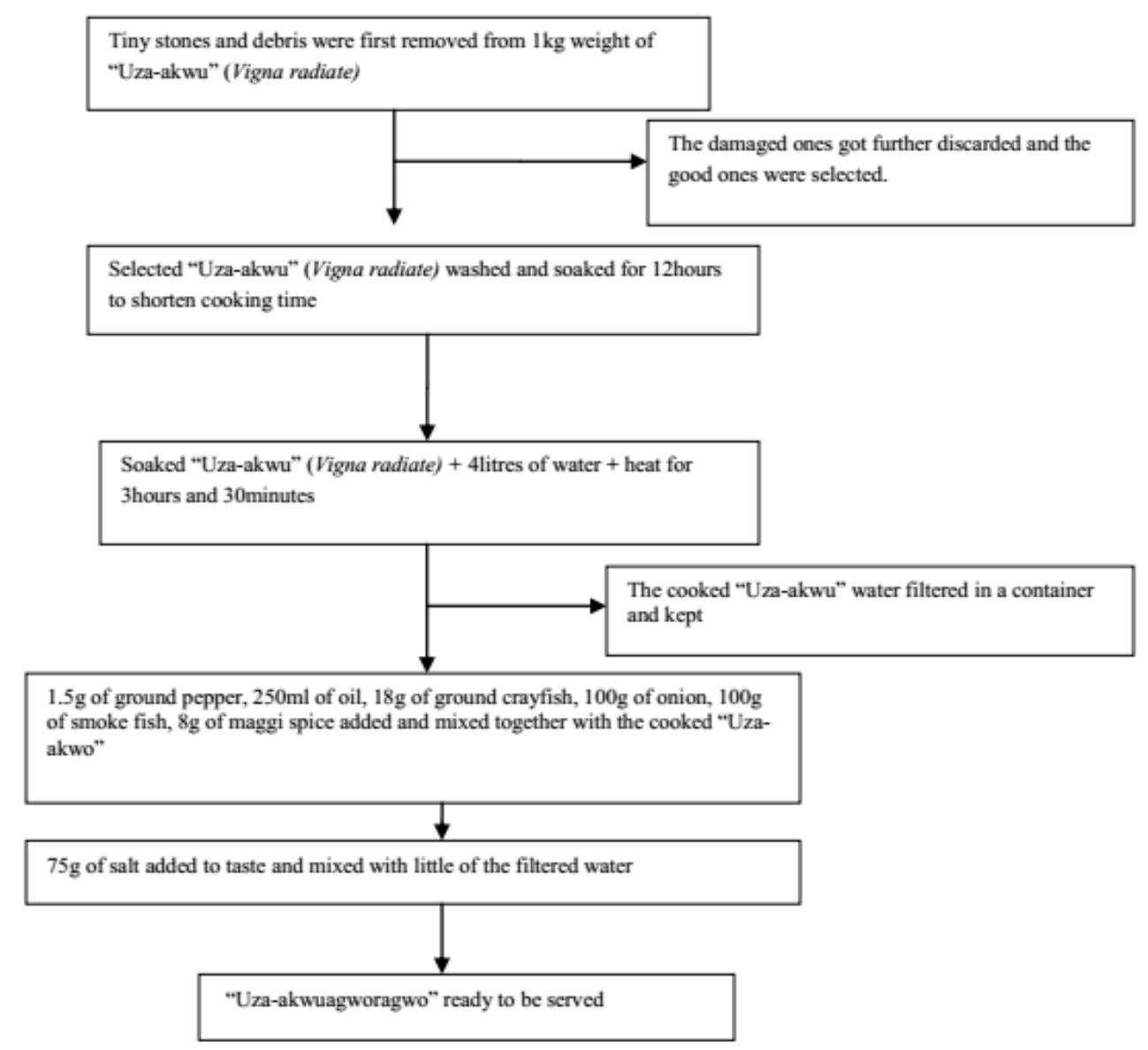

Fig. 1: Flow-chart for preparation of "uza-akwuagworagwo" traditional foods 


\section{Determination of total vitamin}

Five grams of the sample was weighed into an extraction bottle and $20 \mathrm{ml}$ of the extractant (1:1) of methanol and ethanol was added. The mixture was sonicated at $30{ }^{\circ} \mathrm{C}$ for $1 \mathrm{hr}$. The extract was decanted and $10 \mathrm{ml}$ of hexane was added to the extract. Five $\mathrm{ml}$ of trifluoroacetic acid was added to mixture and refluxed for $10 \mathrm{~min}$. The extract was read on UVvisible spectrophotometer at a wavelength of $280 \mathrm{~nm}$. Aqueous stock solution of vitamins were prepared and used to calibrate the equipment, and the concentration of the total vitamins was calculated from the calibration graph.

\section{Phytochemical analysis}

Alkaloids, saponins, tannins, glycosides, and flavonoids of the studied sample were screened using the methods of Harborne [32] whereas their quantitative determinations were done using the methods of AOAC [30].

\section{Sensory evaluation}

The sensory evaluation of the studied food was conducted in Department of Chemical Sciences (Biochemistry Unit) Laboratory where the food was prepared. Twenty students, seven mothers, six non-teaching members of staff and six lecturers of Rhema University were randomly selected and trained. Each of the panelists was seated in an individual compartment from distraction and was served the freshly prepared "uza-akwuagworagwo". The judges evaluated the sample for flavour, taste, colour, texture and overall acceptability using a nine point hedonic scale, where 9 was the highest score and 1 the lowest. This was done in line with the method described by Amadi et al. [33] and Onwuka [34].

\section{RESULTS AND DISCUSSION}

Table 1 shows the proximate composition of "uzaakwuagworagwo" traditional food. The observed moisture $(10.00 \pm 1.90 \%)$ in the studied food is higher than that of "nduduagworagwo" [29] but lower than those of "onunu" and "mgbam" [19], and "tarhana sample with whole meal flour $(85.90 \pm 0.20 \%)$ traditional foods. High moisture content in food has been shown to encourage microbial growth $[7,14,21 ; 29,35]$. The implication of this could be that the studied food sample may have relatively long shelf-life against "onunu", "mgbam", and "tarhana sample with whole meal flour but a lower one against "nduduagworagwo". According to Akubugwo et al. [36], ash content in foods of plant origin is an index of mineral contents. Ash content of "uza-akwuagworagwo" (4.12 $\pm 0.20 \%)$ is higher than that of "onunu" [11], lower than that of "mgbam" $(6.85 \pm 0.14 \%)$ [19] and could be

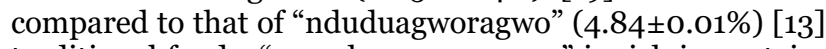
traditional foods. "uza-akwuagworagwo" is rich in protein. The crude protein $(39.81 \pm 2.84 \%)$ of the studied food sample is higher than that of "nduduagworagwo" $(12.12 \pm 0.04 \%)$, and "onunu" $(13.12 \pm 1.42 \%)$; but is comparable to that of "mgbam" $(30.63 \pm 0.23 \%)$ traditional foods of Nigerian origin. The high protein content of the studied food could be indication that the food can contribute significantly to daily human protein requirements, usually about 23-56g [37]. The observed crude fat $(21.00 \pm 3.07 \%)$ was next to the highest after crude protein in terms of proximate contents of the studied food sample. The crude fat content is the highest when compared to those of "nduduagworagwo" (18.75 $\pm 0.06 \%)$, and "onunu" (11.65 $\pm 0.53 \%)$ but lower than that of "mgbam" $(36.35 \pm 2.32 \%)$ traditional foods. Studies revealed that the usage of traditional food can reduce the incidence of many life style diseases [38-41]. These benefits could be derivable by consuming the studied food sample which recorded highest fiber content of $17.87 \pm 1.10 \%$, when compared to those of "nduduagworagwo" ( $3.15 \pm 0.09 \%)$, "onunu" $(9.90 \pm 1.03 \%)$, and "mgbam," (3.78 $\pm 0.12 \%)$ traditional foods. Recorded available carbohydrate for "uzaakwuagworagwo" (15.68 $\pm 0.32 \%)$ is lower than of "nduduagworagwo" (59.00 $\pm 0.01 \%)$ but higher than those of "onunu" (3.80 $\pm 0.26 \%)$ and "mgbam" (6.8 $\pm 0.14 \%)$ traditional foods. The calculated energy value for the studied food sample $(251.96 \pm 2.80 \%)$ could be an indication that the food is not a good energy giving food when compared to those of "nduduagworagwo" (453.19 $\pm 0.15 \mathrm{Kcal} / 100 \mathrm{~g})$, "onunu (348.25 $\pm 4.12 \mathrm{Kcal} / 100 \mathrm{O})$ and "mgbam" $(499.39 \pm 48.73 \mathrm{Kcal} / 100 \mathrm{)})$.

Table 1: Proximate composition of "uza-akwuagworagwo" traditional food

\begin{tabular}{ll}
\hline Proximate composition & "uza-akwuagworagwo" \\
\hline Moisture content (\%) & $10.00 \pm 1.90$ \\
Ash content (\%) & $4.12 \pm 0.20$ \\
Crude protein (\%) & $39.81 \pm 2.84$ \\
Crude fat (\%) & $21.00 \pm 3.07$ \\
Crude fiber (\%) & $17.87 \pm 1.10$ \\
Available carbohydrates (\%) & $15.68 \pm 0.32$ \\
Energy value (Kcal/10og) & $251.96 \pm 2.80$ \\
\hline
\end{tabular}

Values are mean and standard deviations of triplicate determinations.

Table 2: Percentage total free fatty acid and total vitamins of "uza-akwuagworagwo" traditional food

\begin{tabular}{ll}
\hline Parameter (\%) & "uza-akwuagworagwo" \\
Total free fatty acid & $14.98 \pm 1.20$ \\
Total vitamins & $26.14 \pm 0.74$ \\
\hline
\end{tabular}

Values are mean and standard deviation of triplicate determinations. 
Different authors have reported the importance of consuming food rich in fatty acids [8, 2, 42-44] and vitamins $[6,9,18,29,45-49]$. A lot of benefit has been given to having fatty acids in foods consumed by humans. Among such benefits are their roles in brain and eye development especially in growing fetus during pregnancy. They also promote the general well-being of the body through maintenance of good health $[41,44,50-51]$. The roles of vitamins in the body cannot be overstated. Vitamins are known to maintain skin, mucus membrane, bones, teeth, hairs, vision, and reproduction. Others include their roles in nervous system, facilitating the release of energy from carbohydrates, helping in blood production and acting as antioxidants that protect cell wall [52-56]. By having total free fatty acids $(14.98 \pm 1.20 \%)$ and total vitamins $(26.14 \pm 0.74 \%)$ in the studied food as stipulated in table 2, here lies the possible benefits of consuming the food as mentioned above.

"uza-akwuagworagwo" traditional food showed the presence of important phytochemicals such as alkaloids, flavonoids, tannins, saponins, and phenols when it was screened (table 3). Okaka and Okaka [6] noted that alkaloids, flavonoids, tannins, saponins, and others are mostly biosynthesized intrinsic components and sometimes contribute to food colour and flavor. The concentrations of the detected phytochemicals were subsequently determined quantitatively and presented in table 4 . Observed alkaloids $(1.71 \pm 0.10 \mathrm{mg} / 100 \mathrm{~g})$ for the studied food sample is lower than that of "onunu" $(5.06 \pm 1.05 \mathrm{mg} / 100 \mathrm{~g})$ and could be compared to that of "mgbam" $(1.82 \pm 0.10 \mathrm{mg} / 100 \mathrm{)}$ [19]. Flavonoids content of "uza-akwuagworagwo" $(3.68 \pm 0.00 \mathrm{mg} / 100 \mathrm{~g})$ is the lowest compared to those of "onunu" (23.76 \pm 0.18 $\mathrm{mg} / 100 \mathrm{~g})$ and "mgbam" (77.88 $\pm 2.00 \mathrm{mg} / 100 \mathrm{~g})$.
Observed tannins (0.64 $\pm 0.12 \mathrm{mg} / 100 \mathrm{~g})$, saponins (0.94 $\pm 0.31 \mathrm{mg} / 100 \mathrm{~g})$ and phenols $(0.04 \pm 0.00 \mathrm{mg} / 100 \mathrm{~g})$ for "uza-akwuagworagwo" were the lowest when compared to those of "onunu" and "mgbam" traditional foods of Ikwerre ethnic national in Nigeria [19]. It has been noted that under certain circumstances, phytochemicals in food materials are beneficial to the body. For instance, tannins are effective against wound healing and inflamed mucous membranes [57-58]. The beneficial effect of saponins has been reported by Seigler [59], Sadipo and Akiniyi [6o], Osuagwu et al. [61], Stone, and Sidel [62], and Enig [63]; while some of the negative impact on food materials has also been reported by Duru et al. [64] and Duru et al. [65].

Sensory evaluation has been noted as a scientific method that evaluates dishes for improvements, and determines acceptable and unacceptable nature of food samples [66]. Table 5 shows the sensory evaluation of "uzaakwuagworagwo" traditional food. From the Table, attributes of sensory evaluation for the food were appearance $(5.31 \pm 0.29)$, taste $(7.00 \pm 1.02)$, aroma (7.31 \pm 0.29$)$, texture $(5.70 \pm 1.01)$, colour $(6.22 \pm 0.92)$, and overall acceptability $(6.10 \pm 0.31)$. Sensory evaluation compares similarities and differences among dishes and food products [63]. The studied food sample had a poor appearance $(5.31 \pm 0.29)$ when compared to those of "nduduagworagwo" (7.59 \pm 0.25$)$ and "ntiti-ikpa" $(7.35 \pm 0.67)$ traditional foods. The texture (mouth feel) is low compared to those of "ntubiri" and "ntiti-ikpa" traditional foods while its taste, aroma, colour and overall acceptability could be compared to those "nduduagworagwo", "ntubiri" and "ntiti-ikpa" traditional foods of Nigerian origin.

Table 3: Phytochemical screening of "uza-akwuagworagwo" traditional food

\begin{tabular}{ll}
\hline Phytochemical content & "uza-akwuagworagwo" \\
\hline Alkaloids & ++ \\
Flavonoids & ++ \\
Tannins & + \\
Saponins & + \\
Phenols & + \\
\hline
\end{tabular}

Table 4: Phytochemical composition of "uza-akwuagworagwo traditional food

\begin{tabular}{ll}
\hline Parameters (mg/100g) & "uza-akwuagworagwo" \\
\hline Alkaloids & $1.71 \pm 0.10$ \\
Flavonoids & $3.68 \pm 0.00$ \\
Tannins & $0.64 \pm 0.12$ \\
Saponins & $0.94 \pm 0.31$ \\
Phenols & $0.04 \pm 0.00$ \\
\hline
\end{tabular}

Values are means and standard deviation of triplicate determinations.

Table 5: Sensory evaluation of "uza-akwuagworagwo" traditional food

\begin{tabular}{ll}
\hline Attributes & "uza-akwuagworagwo" \\
\hline Appearance & $5 \cdot 31 \pm 0.29$ \\
Taste & $7.00 \pm 1.02$ \\
Aroma & $7 \cdot 31 \pm 0.29$ \\
Texture(Mouth feel) & $5 \cdot 70 \pm 1.01$ \\
Colour & $6.22 \pm 0.92$ \\
Overall acceptability & $6.10 \pm 0.31$ \\
\hline
\end{tabular}

Values are mean and standard deviation of 39 panelists. 


\section{CONCLUSION}

"uza-akwuagworagwo" is a protein rich food and could contribute significantly to the daily protein requirement of the body. Also, the low levels of the observed phytochemicals in the food could be an added health advantage on consuming the food, while its overall acceptability compares with those of other traditional foods of Nigerian origin. This study has revealed the proximate, phytochemical, and sensory evaluation of "uzaakwuagworagwo" and traditional food of Nkanu people in Enugu State, Nigeria.

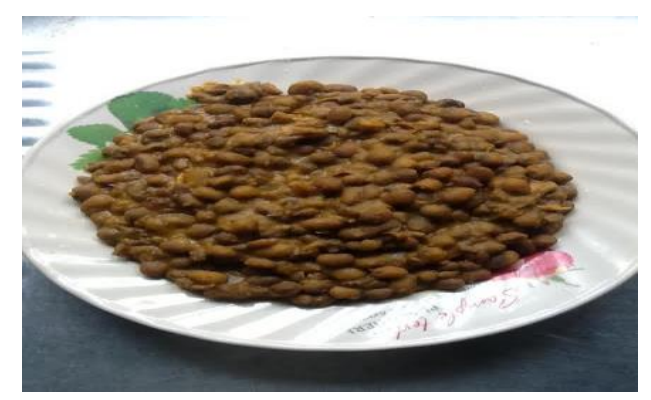

Fig. 2: Picture of a freshly prepared "uzaakwuagworagwo

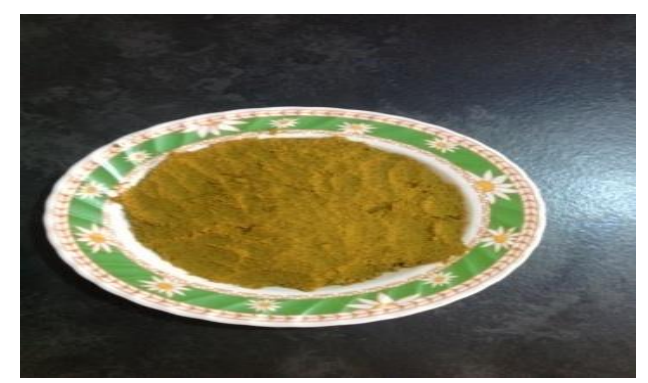

Fig. 3: Picture of ground "uza-akwuagworagwo

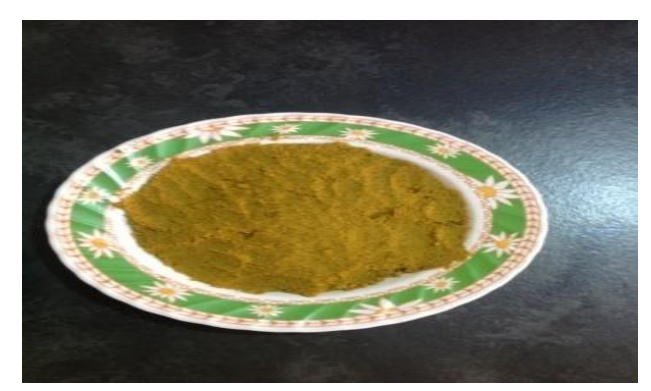

Fig. 4: Picture of oil extracted from "uzaakwuagworagwo" used for fatty acid analysis

\section{REFERENCES}

1. Marlowe, F. W. Hunter-gatherers and human evolution. Evolutionary Anthropology: Issues, News, and Reviews, 2005;14 (2): 54-67.

2. Duru, M., Amadi, B., Arukwe, U., Adindu, E., Amadi, C., and Onuoha, N. Fatty acid composition and sensory evaluation of "Nduduagworagwo" a local food of Akokwa people in Imo State, Nigeria. Global Research Journal of Science, 2013;2(2):67-77.

3. World Health Organization. Declaration of Alma Ata: International Conference on Primary Healthcare, Alma Ata, USSR.6-12 September, 1978. www. who. int/hpr/NPH/does/declaration-almaata. pdf

4. Duru, M., and Nwanekwu, K. Assessment of Urine on Body Weight, CD4 Cells and Testosterone Hormone. Canadian Journal on Computing in Mathematics, Natural Sciences, Engineering and Medicine, 2013;4 (1): 56-6o.

5. Duru, M., Nwanekwu, K., Ugbogu, A., Joseph, A., Amadi, C., and Ujubuonu, P. Urine therapy and its effects on some biochemical parameters using rats. Continental J. Biomedical Sciences, 2012;7(1): 12-17.

6. Okaka, J. C., and Okaka, A. N. C. Foods: composition spoilage and shelf-life extension 1st edition. Ocjanco Publishers, Enugu. 2005;pp. 20-21, 52-56.

7. Olusanya, J. O. Essentials of food and nutrition,1st edtion, Apex Book limited, Lagos, 2008;pp. 36-75.

8. Duru, M., Ugbogu, A., Amadi, A., Odika, P., ChimaEzika, O., Anudike, J., and Osuocha, K. Chemical constituents of Buchholzia coriacea seed. Proceedings of the 35th Annual International Conference, Workshop and Exhibition of Chemical Society of Nigeria. Volume 2, 2012;pp.39-45.

9. Duru, M., Amadi, B., and Njoku, V. Evaluation of some chemical constituents of "ji-otor" and "ntubiriikpa" traditional foods of Ikwerre ethnic national in Nigeria. Proceedings of the 36th Annual International Conference of Chemical Society of Nigeria, 2013;pp.38-44.

10. Duru, M. K. C., Amadi, B. A., Nwadike, N. C., and Ozougwu, J. Anti-nutrients, amino acid quality and performance characteristics of "Nduduagworagwo" traditional diet. Journal of Microbiology, Biotechnology and Food Sciences 2015;4(3): 252-256.

11. Amadi, B. A., Duru, M. K. C., Eze, A. A., and Amadi, C. T. Sensory evaluation, mineral, and amino acid composition of "Ntubiri" and "Ntiti-ikpa", traditional foods of Ikwerre ethnic nationality in Nigeria". The Pacific Journal of Science and Technology 2013;14(1):295-300.

12. Cayot, N. Sensory quality of traditional foods. Food Chemistry, 2007;102:445-445.

13. Duru, M. K., Amadi, B. A., Amadi, C. T., Ugbogu, A. E., and Onuoha, N. L. Assessment "Nduduagworagwo", a traditional recipe of Akokwa people in Ideato North L. G. A of Imo State, Nigeria on body weight and some biochemical parameters. Continental J. Food Science and Technology, 2012;7(1):15-21.

14. Amadi, B. A., Arukwe, U., Duru, M. K. C., Adindu, E. A., Ufornwa, E. C., and Odika, P. C. The effect of fermentation on anti-nutrients, carbohydrates and vitamin contents of Pentaclethra macrophylla seed. International Science Research Journal 2011;3:74-77.

15. Amadi, B. A., and Duru, M. K. C. Amino acid quality and performance characteristics of "Ji-oto" traditional food of Ikwerre of Rivers State, Nigeria. Pacific Journal of Science and Technology, 2014;15(2):228-239.

16. Amadi., B. A., Duru, M. K. C., and Ayalogu, E. O. Proximate and anti-nutritional composition of "Ntitiikpa", and "Ntubiri", traditional diets of the Ikwerre ethinic national in Nigeria. Elixir Food Science, 2014;71:24751-24754. 
17. Amadi, B., Duru, M., Agomuo, E., Amadi, P., and Onedibe, O. Nutritional, phytochemical and sensory evaluation of "Mberiagworagwo" traditional food of Uruagunnewi people in Anambra State, Nigeria. Journal of Advances in Botany and Biotechnology, 2017;14 (1).1-5.

18. Amadi, B., Onuoha, N., Amadi, C., Ugbogu, A., and Duru, M. Elemental amino acid and phytochemical constituents of fruits of three different species of eggplant. Int. J. Med. Arom. Plants, 2013a; 3(2): 220203.

19. Amadi B, A., Ayalogu E. O., and Onyeike E. N. Nutrient and antinutrient composition of "Onunu" and "Mgbam", traditional foods of Ikwerre ethnic nationality in south-southern Nigeria. Journal of Emerging Trends in Engineering and Applied Sciences, 2011b; 2 (3): 551-555.

20. Duru, M., Amadi, B., Eze, A., and Ugbogu, A. Evaluation of "Mgbam" traditional food on haematological profile and some selected biochemical parameters following consumption. Elixir Food Science 2013b; 64:19345-19349.

21. Temple, V. J., Badamosi, E. J., Ladeji, O., and Solomon, M. Proximate chemical composition of three locally formulated complementary foods. West African J. of Biol. Sci, 1996;5:134-143.

22. Achi, O. K. Traditional fermented protein condiments in Nigeria. African Journal of Biotechnology, 2005, 4 (13): 161-162.

23. Kpikpi, E. N., Dzogbefia, V. P., and Glover, R. K. Enzymatic and some biochemical changes associated with the production of "Kantong", a traditional fermented condiments in Northern Ghana. J. of Food Chem, 2009;33 (1): 61-73.

24. Kristbergsson, K., and Oliveira, J. Traditional Foods: General and Consumer Aspects. Integrating Food Science and Engineering Knowledge into the Food Chain. Springer US, 2016;pp. 85-86. ISBN 978-14899-7648-2.

25. Duru, M., Amadi, B., Ugbogu, A., and Onuoha, N. Effect of "Nduduagworagwo" traditional food on haematology, hepatic and renal function of rats. Asian Journal of Agriculture and Food Science, 2013;1(1):21-26.

26. Ibanoglu, S., Ainswoth, P., Wilson, G and Hayes, D. G. The effect of fermentation conditions on the nutrients and acceptability of tarhana. Food chemistry, 1995;53:143-147.

27. Trichopoulou, A., Vasilopoulou, E., Georga, K., Soukara S., and Dilis V. Traditional foods: Why and how to sustain them. Trends in Food Science and Technology, 2006;17:498-504.

28. Trichopoulou A., Soukara S., and Vasilopoulou, E. Traditional foods: a science and society perspective. Trends in Food Science and Technology, 2007;18:420427.

29. Duru M. K. C; Agomuo E. A; and Amadi B. A. Nutrient composition of "Nduduagworagwo", a traditional food of Akokwa people in Ideato North L. G. A of Imo State, Nigeria. Continental J. Food Science and Technology 2012;6 (3): 27-32. doi: 10.5707/cjfst.2012.6.3.19.26.

30. AOAC (Association of Official Analytical Chemists) Official method of analysis of the AOAC (W. Horwitz Edition) 18th edition, Washington DC, 2006.

31. Onyeike, E. N., Olungwe,T., and Uwakwe, A. A. Effects of heat treatment and defatting on the proximate composition of some Nigerian local soups thickeners. Food Chemistry 1995;53:35-39.
32. Harbone, J. B. Phytochemical methods, a guide to modern technique of plants analysis.2nd edn., Chapman and Hall, New York, 1973.

33. Amadi, B. A., Agomuo, E. N., and Ibegbulem, C. O. Research methods in Biochemistry, Supreme Publishers, Owerri, Imo State, Nigeria. 2005;pp. 6669.

34. Onwuka, G. I. Food analysis and instrumentation theory and practice, 1st edition, Naphthali prints, Surulere, Lagos, 2005;p.140.

35. Arukwe, U., Amadi, B. A., Duru, M. K. C., Agomuo, E. N., Adindu, E. A., Odika, P. C., Egejuru, L., and Anudike, J. Chemical composition of Persea americana leaf, fruit and seed. IJRRAS, 2012;11(2): 355-358.

36. Akubugwo, I.E., N. A. Obasi, G. C. Chinyere, and A. E. Ugbogu, Nutritional and chemical value of Amaranthus hybridus L. leaves from Afikpo, Nigeria. African Journal of Biotechnology, 2007;6(24): 2833-2839.

37. $\mathrm{FAO} / \mathrm{WHO} / \mathrm{UNU}$. Energy and protein requirements: Report of a joint $\mathrm{FAO} / \mathrm{WHO} / \mathrm{UNU}$ expert consultation. WHO technical report series 724, 1991. ISSN 0512-3054. Http://www. fao. org/docrep/o03/aa040e/AA040E01. htm.

38. FAO. Root, tubers, plantains, and bananas in human nutrition. FAO corporate document repository. Rome, Italy, 1990. http://www. fao. org/docrep/o03/aa040/AA 040E01.

39. SACN. Draft SACN position statement on diaetry fibre and health and the dietary fibre definition. August 2008. SAC N/08/20. http://www. sacn. gov. $\mathrm{uk} / \mathrm{pdfs} /$ final__ draft__ sacnstatement _on_dietary_fibre_for_website.pdf.

40. Walker, A. R. P. The relationship between bowel and cancer and fiber content in the diet. Am. J. Clin. Nutr., 1987;31:S248-S251.

41. Dillard, C. J. and German, J. B. Phytochemicals; nutraceuticals and human health. J. Sci. Food Agric., 2000;80(12):1744-1756.

42. Ruyle, M., Connor, W. E., Anderson, G. I., and Lowensohn, R. L. Placental transfer of essential fatty acids in humans: venous arterial difference for docosahexanoic acid in fetal umblical erythrocytes. Proc Natl Acad Sci USA. 1990;87:7902-7906

43. Fite, B. The Healing miracle of coconut oil. Piccadilly Books Ltd, Healthwise Publications Colorado Springs, Co., 2000;pp. 1-4.

44. Rodriguez-Cruz, M., Tovar, A. R., Del Prado, M., and Torres, N. Molecular mechanisms of action and health benefits of polyunsaturated fatty acids. Revista $d$ Investigación Clínica; Organo del Hospital de Enfermedades de la Nutrición. 2005;57, 457-472.

45. Duru, M., Amadi, C. T., Ugbogu, A., Eze, A., and Amadi, B. Phytochemical, vitamin and proximate composition of Dacryodes edulis fruit at different stages of maturation. Asian Journal of Plant Science and Research, 2012;2 (4):437-441.

46. Okwu, D. E. Phytochemicals, vitamins and mineral contents of two Nigerian medicinal plants. Int. J. Mol. Adv. Sci. 2005;1(4):375-381.

47. Nkafamiya, I. I., Oseameahon, S. A., Mobibbo, U. U., and Haggai, D. (2010). Vitamins and effect of bleaching on nutritional and antinutritional values of non-convectional leafy vegetable. African Journal of food Science, 2010;4(6): 335-341.

48. Amadi, B. A., Duru, M. K. C., and Agomuo, E. N. Chemical profiles of leaf, stem, root and flower of 
Ageratum conyzoides. Asian Journal of Plant Science and Research, 2012;2(4):482-483.

49. Amadi, B. A., Arukwe, U., Duru, M. K. C., Amadi, C. T., Adindu, E. A., Egejuru, L., and Odika, P. C. Phytonutrients and antinutrients screening of $D$. edulis fruits at different maturation stages. J. Nat. Prod. Plant Resour, 2012;2(4):530-533.

50. Neugringer, M., Connor, W. E., Van petten, C., and Barstad, L. Dietary omega-3 fatty acids deficiency and visual loss in infant reheus monkeys. J. Clin Invest., 1984;73:272-276

51. Neugringer, M., Connor, W. E., Lin, D. S., Barstad, L., and Luck, S. Biochemical and functional effects of prenatal and postnatal omega- 3 fatty acid deficiency on retina and brain in rehesus monkeys. Proc Natl Acad Sci. USA., 1986;83:4021-4025.

52. Ihekoronye, C. I., and Ngoddy, P. O. Integrated food science and technology for the tropics. Macmillian Publishers Ltd, London, 1985.

53. Julie, B. The importance of vitamin and their role in our body. Ezinne Article, 2003 pp. 1-5.

54. Paul, G. The vitamin, 1st edn., Academic press, New York, USA, 1967;pp. 40-47.

55. Paul, G. and Pearson, S. The Vitamin, $2^{\text {nd }}$ edn., Academic Press, New York, USA, 2005;pp.31-32.

56. Charlene, J. N. The importance of vitamins to our body. Health Guidance, 2003;pp.1-2

57. Kozioc, M. J., and Marcia, M. J. Chemical composition, nutritional evaluation and economic prospects of Spondias purpurem (Anarcadiacea). Economic Botany, 1998;52:373-380.
58. Okwu, D. E. Phytochemicals and vitamin content of indigenous spices of South Eastern Nigeria. Journal of Sustaining Agricultural Environment, 2004;6:30-34.

59. Seigler, D. S. Plants with saponinsans cardiac glycosides, 1998 . www. lifwe. vinc. edu/plantbio/363/saponinslises.

6o. Sodipo, O. A., and Akiniyi, J. A. Studies on certain characteristics of extracts from bark of Pansinystalia macruceras (K. schum) Pierre Exbeille. Global Journal of Pure and Applied Science, 2000;6:83-87.

61. Osuagwu, G. G. E., Okwulehie, I. C., and Emenike, J. O. Phytochemical and mineral content of the leaves of four Nigeria Pterocarpus (JACO) species. International Journal of Medicine and Advance Sciences, 2007;3(1): 6-11.

62. Stone, H., and Sidel. J. L. Sensory evaluation practices. Academic Press: Los Angeles, CA, 1993.

63. Enig, M. Coconut: In support of good health in the 21st century., 1990, pp.1-27. Available at http. www. coconutoil. com/coconut-oil-21st century. htm (Accessed on September 18th 2011).

64. Duru, M., Nwadike, C., Ezekwe, A., Nwaogwugwu, C., Eboagwu, I., Odika, P., Njoku, S., and Chukwudoruo, C. Evaluation of nutritional, anti-nutritional and some biochemical studies on Pleurotus squarrosulus (Mont.) singer using rats. African Journal of Biochemistry Research, 2018;12 (2):7-27.

65. Duru, M., Ugbogu, A and Amadi, B. Effect of Solanum macrocarpon fruit on haematoloy, hepatic and renal function. Advances in Biochemistry, 2013;1(2): 2832.

66. British Human Foundation. Food: a fact of life. www. foodafactoflife. org. uk, 2010. 